\section{A NEW ANTIBIOTIC, LIPOPEPTIN A}

Sir:

We wish to describe here isolation and characterization of a new antibiotic from cultures of Streptomyces sp. No. AC-69, which resembles Streptomyces violaceochromogenes. This strain was isolated from a soil sample collected in Futaba-gun, Fukushima Prefecture, Japan.

The strain was cultured at $27^{\circ} \mathrm{C}$ for 72 hours in a jar fermentor containing 30 liters of a medium, which is composed of $2 \%$ glucose, $1 \%$ soluble starch, $0.1 \%$ meat extract, $0.4 \%$ dry yeast, $2.5 \%$ soybean flour, $0.2 \% \mathrm{NaCl}$ and $0.005 \% \mathrm{~K}_{2} \mathrm{HPO}_{4}$. Fermentation broth was adjusted to $\mathrm{pH} 2.0$ with $10 \% \mathrm{HCl}$, heated for 10 minutes at $60^{\circ} \mathrm{C}$ and filtered. The filtrate was extracted twice with 30 liters of ethyl acetate. Mycelium was extracted with 15 liters of $80 \%$ acetone, the extract was concentrated in vacuo to give an aqueous solution (4 liters), and this was then extracted twice with 4 liters of ethyl acetate. All the ethyl acetate extracts were combined and concentrated in vacuo to dryness. The residue was purified with the following successive chromatographies: (1) Silicic acid (isopropanol-0.1 $\mathrm{N} \mathrm{NH}_{4} \mathrm{OH}, 5: 0.2 \rightarrow$ 5: 1), (2) Sephadex LH-20 (methanol), (3) DEAEsepharose (carbonate form, $60 \%$ methanol $\rightarrow$ $0.5 \mathrm{M} \mathrm{NH}_{4} \mathrm{HCO}_{3}$-methanol, 4:6), (4) Diaion HP-20 (water $\rightarrow$ methanol).

The antibiotic was obtained as purified white powder $(600 \mathrm{mg})$ from methanol - ether. H.p.l.c. analysis showed that it contained a major component and a minor component. Separation was achieved by repeated preparative chromatography using a Hitachi RP-18 column with methanol containing $0.5 \% \quad \mathrm{H}_{3} \mathrm{PO}_{4}$ and $30 \% \mathrm{H}_{2} \mathrm{O}$. Main fraction was collected and neutralized with dilute $\mathrm{NH}_{4} \mathrm{OH}$. After adsorption and elution from Diaion HP-20, $390 \mathrm{mg}$ of lipopeptin A was obtained as white powder from methanol - ether.

Lipopeptin A free acid melted at $206 \sim 208^{\circ} \mathrm{C}$ with decomposition. It is optically active, $[\alpha]_{D}^{20}$ $-45.4^{\circ}$ ( $c$ 1.06, methanol).

Anal. Calcd. for $\mathrm{C}_{54} \mathrm{H}_{84} \mathrm{~N}_{10} \mathrm{O}_{19} \cdot 2 \mathrm{H}_{2} \mathrm{O}$ : C 53.47, H 7.26, N 11.55, O 27.72.

Found: C 53.55, H 7.22, N 11.55, O 26.39.

FD mass spectrum showed $(\mathrm{M}+\mathrm{Na})^{+}, 1,199$. Electrometric titration showed it is a dibasic acid with a $\mathrm{pKa}^{\prime}$ of 4.6 and titration equivalent of 587. It is soluble in lower alcohols, sparingly soluble in acetone, chloroform, ethyl acetate, and hardly soluble in benzene, ether and petroleum ether. It is positive to DRAGENDORFF and RYDONSmith tests but negative to a ninhydrin test. It showed end absorption in UV region. The IR absorption spectrum is shown in Fig. 1. The presence of amide $\left(1650\right.$ and $\left.1525 \mathrm{~cm}^{-1}\right)$ and ester $\left(1735 \mathrm{~cm}^{-1}\right)$ was suggested. On acid hydrolysis, the following amino acids were identified; serine, threonine, aspartic acid, glutamic acid, $N$ methylaspartic acid, $N$-methylphenylalanine, and threo- $\beta$-hydroxyglutamic acid. In addition, saturated $\mathrm{C}_{15}$-fatty acid was isolated and charac-

Fig. 1. IR absorption spectrum of lipopeptin $\mathrm{A}$ (in $\mathrm{KBr}$ ).

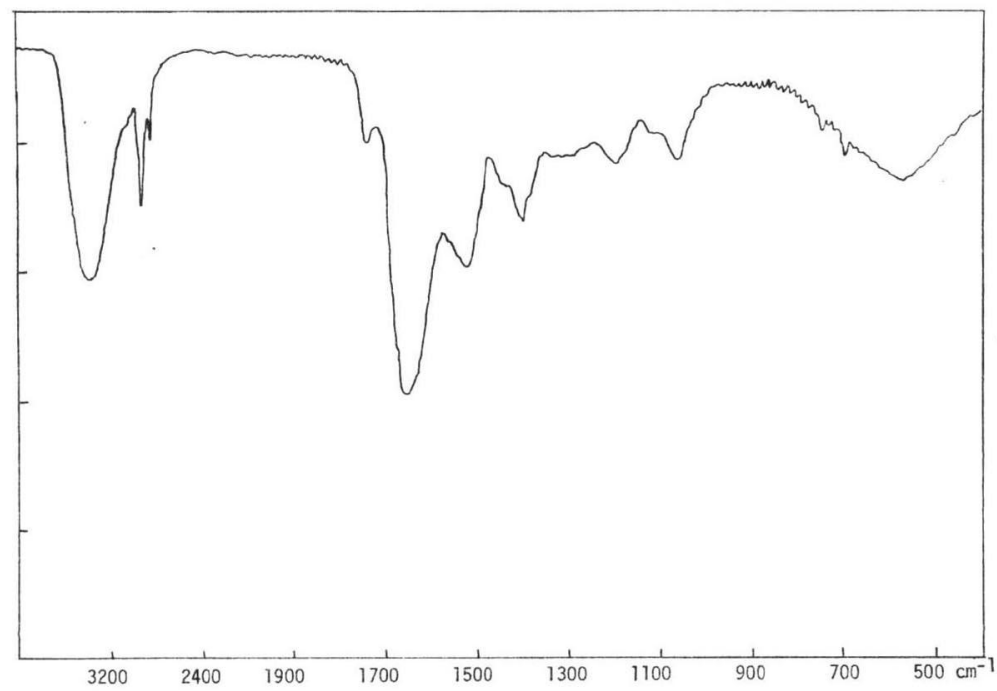


Table 1. Antifungal activity of lipopeptin A.

\begin{tabular}{l|c}
\hline \multicolumn{1}{c|}{ Microorganism } & MIC $(\mu \mathrm{g} / \mathrm{ml})$ \\
\hline Piricularia oryzae & 150 \\
Colletotrichum lagenarium & 150 \\
Alternaria mali & $>300^{*}$ \\
Botrytis cinerea & $>300^{*}$ \\
Cochliobolus miyabeanus & $>300^{*}$ \\
\hline
\end{tabular}

Conventional agar dilution method was employed using potato-sucrose medium.

* Partial inhibition was observed at this concentration.

terized by mass spectroscopy.

The antibiotic showed weak inhibitory activity against some species of phytopathogenic fungi (Table 1). It caused swelling of fungal cells. It also inhibited peptidoglycan synthesis of Escherichia coli $\mathrm{Y}-10$ in vitro $\left(\mathrm{I}_{50} 150 \mu \mathrm{g} / \mathrm{ml}\right)$. However, it showed only a very weak inhibitory activity against bacteria cells. Mice tolerated $250 \mathrm{mg}$ per $\mathrm{kg}$ of body weight of intravenous injection of lipopeptin A.
Acknowledgment

We are grateful to Prof. T. SHIBA, Osaka University, Prof. H. Vanderhaeghe, Katholieke Universiteit Leuven, and Drs. M. EbATA and J. SHOJ, Shionogi Research Laboratories for their gifts of reference amino acids.

\section{Kiyoshi Tsuda $†$ \\ TSUYOSHI KIHARA \\ Masahiro NishiI \\ GOTO NAKAMURA \\ KIYOSHI ISONO* \\ Saburo SuzukI††}

Antibiotics Laboratory

The Institute of Physical and

Chemical Research, Wako-shi,

Saitama 351, Japan

(Received November 7, 1979)

* To whom all correspondence should be addressed.

$\dagger$ Present address: Central Research Laboratories, Kaken Chemical Co., Ltd., Jujodai, Kita-ku, Tokyo 114.

$\dagger \dagger$ Present address: Ohtsuma Women's University, Irima, Saitama. 